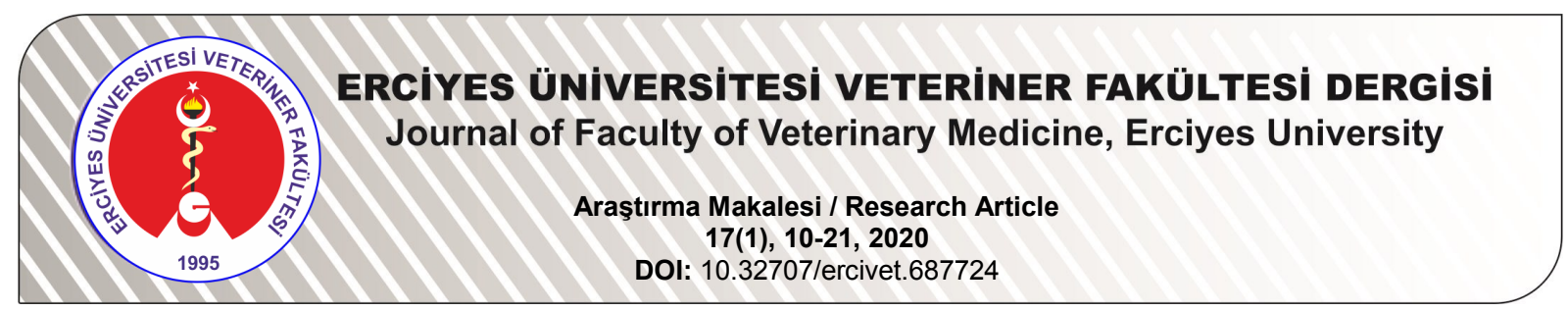

\title{
Aydın/Bozdoğan Yöresinde Yetiştirilen Gökkuşağı Alabalıklarında (Oncorhynchus mykiss) Paraziter Yaygınlığın Araştırılması (*)(**)
}

\author{
Emrah ŞiMŞEK ${ }^{1}$, Osman Selçuk ALDEMiR ${ }^{2}$ \\ ${ }^{1}$ Erciyes Üniversitesi, Veteriner Fakültesi, Su Ürünleri ve Hastalıkları Anabilim Dalı, Kayseri, TÜRKIYE \\ ${ }^{2}$ Adnan Menderes Üniversitesi, Veteriner Fakültesi, Parazitoloji Anabilim Dalı, Aydın, TÜRKIYE
}

\begin{abstract}
Sorumlu yazar: Emrah ŞiMŞEK; E-posta: emrahsimsek@erciyes.edu.tr ORCID: 0000-0002-0492-9840
Atıf yapmak için: Şimşek E, Aldemir OS. Aydın/Bozdoğan yöresinde yetiştirilen gökkuşağı alabalıklarında (Oncorhynchus mykiss) paraziter yaygınlığın araştııııması. Erciyes Üniv Vet Fak Derg 2020; 17(1):10-21.
\end{abstract}

Özet: Çalışma, Aydın/Bozdoğan İlçesi sınırları içinde, Akçay üzerinde kurulu olan Kemer Barajı (37³0' Kuzey enlemi $28^{\circ} 35^{\prime}$ Doğu boylamı)'ndaki kafeslerde ve Akçay üzerindeki havuzlarda yetiştiriciliği yapılan gökkuşağı alabalıklarında (Oncorhynchus mykiss) paraziter yaygınlığı belirlemek amacıyla Eylül 2013-Ağustos 2014 tarihleri arasında gerçekleştirilmiştir. Incelenen 348 balıktan 153'ünün (\%44) çeşitli metazoon ve protozoonlarla enfekte olduğu saptanmıştır. Enfeksiyon saptanan balıkların; 118'i (\%33.9) Trichodina fultoni, 19'u (\%5.4) Ichthyophthirius multifiliis, 5'i (\%1.4) Apiosoma sp., 4'ü (\%1.1) Lernaea sp., olmak üzere tek türle enfekte iken, 7 'sinde $(\% 2)$ ise $T$. fultoni $+I$. multifiliis $(\%$ 1.4) ve T. fultoni + Apiosoma sp. (\%0.6)'den kaynaklanan miks enfeksiyon tespit edilmiştir. Bulunan parazitlerin enfeksiyon oluşturmasında etkili olduğu düşünülen bazı parametrelerin etki paylarının belirlenmesi amacıyla lojistik regresyon analizi yapılmıştır. Buna göre, kış mevsiminde enfeksiyon görülme oranının yaza göre 0.41 kat daha az olduğu ortaya konmuştur. Su sıcaklığındaki bir birimlik $\left({ }^{\circ} \mathrm{C}\right)$ artış enfeksiyonun odds oranını (OR) 1.116 kat artırırken, çözünmüş oksijen miktarındaki bir birimlik artışın $\left(\mathrm{O}_{2} \mathrm{mg} / \mathrm{L}\right)$ ise 0.842 kat azalttığı görülmüştür. Yine aynı şekilde balık boylarındaki bir birimlik (cm) artış enfeksiyonun odds oranını (OR) 0.88 kat azaltırken, ağırlıktaki bir birimlik (g) artışın ise 0.99 kat azalttığı görülmüştür. Sonuç olarak çalışma boyunca incelenen balıklarda \%44 gibi yüksek bir enfeksiyon oranı belirlenmiş olup, tespit edilen parazitler arasında baskın türün T. fultoni olduğu görülmüştür. Özellikle su sıcaklığının arttığı dönemlerde, stok yoğunluğunun fazla olması, suyun yem artıkları ve ölü balıklarla kirletilmesi su kalitesinin bozulmasına sebep olmaktadır. Bu gibi stres faktörlerinin, paraziter enfeksiyonların görülme sıklıklarının artmasında etkili olabileceği belirlenmiştir.

Anahtar kelimeler: Gökkuşağı alabalığı, Ichthyophthirius multifiliis, Lernaea sp., Trichodina fultoni

The Investigation of Parasite Prevalence of Rainbow Trout (Oncorhynchus mykiss) Reared in Aydın/Bozdoğan Province

Summary: This study was carried out to investigate the parasite prevalence on rainbow trout (Oncorhynchus mykiss) which were raised in cage in Kemer Dam Lake built on Akçay River and pools located on the river between September, 2013 and August, 2014. The cage and pools are located between $37^{\circ} 30^{\prime}$ northern $28^{\circ} 35^{\prime}$ eastern longitudes, in Bozdoğan/Aydın, in western Turkey. One hundred fifty three (44\%) fish were detected as positive various protozoans and metazoans at a total of 348 fishes. The number of cases and their percentages values in parenthesis in case of infection with one species are as follows: 118 (33.9\%) T. fultoni, 19 (5.4\%) I. multifiliis, $5(1.4 \%)$ Apiosoma sp., $4(1.1 \%)$ Lernaea sp. Seven of the 153 fishes $(2 \%)$ were infected with mixed infection of $T$. fultoni $+I$. multifiliis $(1.4 \%)$ and T. fultoni + Apiosoma sp. (0.6\%). The logistic regression analysis was done in order to determine the effect share of the parameters which were supposed to have a role in the occurrence of the infection. The analyses indicated that the rate of infection in winter was 0.41 times less than it was in summer. An increase of one unite in water temperature result an 1.116 fold increase in infection odd ratio (OR), while 0.842 fold decrease was observed in response to one unite increase in dissolved oxygen amount $\left(\mathrm{O}_{2} \mathrm{mg} / \mathrm{L}\right)$. Likewise, an increase of one unite in fish length $(\mathrm{cm})$, induced 0.88 fold decrease in infection odd ratio (OR), while an increase of one unite in fish weight $(\mathrm{g})$ caused 0.99 fold reduction in infection odd ratio (OR). Consequently, high infection rate was detected as $44 \%$ and the dominant species among the parasites was observed as T. fultoni. Especially, when the water temperature increase; high stock density and contamination of water with feed residues/dead fish cause water quality to decrease. It was determined that such stress factors may be effective in increasing the prevalence of parasitic infections.

Key words: Ichthyophthirius multifiliis, Lernaea sp., rainbow trout, Trichodina fultoni

Geliş Tarihi/Submission Date : 06.05.2019

Kabul Tarihi/Accepted Date : 06.08.2019

*Bu çalışma, 5-9 Ekim 2015 tarihlerinde Erzurum'da düzenlenen 19 Ulusal Parazitoloji Kongresi ve Uluslararası Katılımlı Ekinokokkozis Sempozyumu'nda sözlü bildiri olarak sunulmuştur.

**Bu çalışma, aynı başıkıı Doktora tezinden özetlenmis olup VTF 14012 kodlu tez projesi kapsamında Adnan Menderes Üniversitesi, Bilimsel Araştırma Projeleri Başkanlığı tarafından desteklenmiştir.

\section{Giriş}

Tatıı sularda ve kısmen de denizlerde yetiştiriciliği yapılan en önemli balık türlerinden birisi gökkuşağı alabalığıdır (Oncorhynchus mykiss). Bu tür, gözlü 
yumurta naklinin kolaylığı, kuluçka süresinin kısa ve hastalıklara karşı dirençli olması nedeniyle dünyanın birçok bölgesine yayılmış olup yetiştiricilikte sıklıkla tercih edilmektedir (Emre, 2004). Yüksek adaptasyon yeteneğine rağmen yetiştiricilik ortamında, doğal koşullardan farklı olarak gelişen bir takım olumsuzluklar sonucu ciddi kayıplar yaşanabilmektedir. Kötü su kalitesi, yetersiz su değişimi, stok yoğunluğunun fazla olması, yetersiz/fazla besleme ve stres gibi faktörlere bağlı oluşan hastalıklar kayıpların başlıca sebepleri arasında yer almaktadır (Pillay, 1992; Öge, 1999; Scholz, 1999). Bu sektörde ürün kaybının en aza indirilebilmesi için hastalık oluşturan etkenlerin bilinmesi ve mücadele çalışmalarının yapılması gerekmektedir. Hastalık etkenlerinin önemli bir bölümünü oluşturan parazitler, balıklarda meydana getirdikleri patojenite sonucu ciddi ekonomik kayıplara sebep olmaktadırlar. Bu kayıplar, yalnızca ölümlerle ilişkili değildir. Hayatta kalan bireylerde gözlenen kondisyon kayıplarının da etkisinin büyük olduğu belirtilmektedir. Konak üreme sisteminde meydana getirdikleri hasarlar sonucunda yeni nesillerin devamlılığı da etkilenmekte ve büyük ekonomik kayıplar yaşanabilmektedir. Aynı zamanda hastalık etkenlerinin oluşturdukları lezyonlara bağlı olarak da balığın kısmi kullanımı söz konusu olmaktadır. Tüm bunların yanı sıra bazı parazitlerin insanlarda enfeksiyon oluşturabilmesinden dolayı zoonotik önemleri de gündeme gelmektedir (Öge, 1999).

Balık parazitleri içinde protozoonlar, monogenea alt sınıfına ait parazitler ve bazı crustacealar büyük yer kaplamaktadırlar. Protozoonlar arasında en yaygın olarak Trichodina, Ichthyophthirius, Epistylis, Apiosoma, Scyphidia, Oodinium ve Chilodonella cinslerine ait türlere rastlanmaktadır. Bu türler sıklıkla konağının deri ve solungaçlarına yerleşim göstermektedirler (Tonguthai, 1997). Copepodlar, crustecealar içinde en yaygın olan patojen parazitler olup, konakta oluşturdukları lezyonların yanı sıra açtıkları yaralardan sekonder bakteriyel enfeksiyon girişine zemin hazırlamaktadırlar (Tonguthai, 1997). Dactylogyrus ve Gyrodactylus gibi deri ve yüzgeçlere yerleşen monogenea cinlerine ait türlerin birçoğu direk yaşam siklusuna sahip olup, genellikle konak spesifiktirler. Konağın solungaç dokularında sayılarının arttığı durumlarda, şiddetli hasara sebep olarak solunumu olumsuz etkileyebilmektedirler (Tonguthai, 1997; Buchmann ve Bresciani, 2006). Trematodlar endoparazitik helmintler olup, bir veya daha fazla ara konak kullanan heteroxene parazitlerdir (Berra ve Au, 1978). Birçok erişkin trematod balıkların sindirim sisteminde parazitlenmekte ve genellikle konak spesifik özellik göstermektedir. Trematod enfeksiyonlarında asıl patojenik etki metaserker döneminde meydana gelmektedir. Metaserkerler erişkinlere göre daha az konak spesifik olup, son konak olan evcil hayvanlar ve insanlarda enfeksiyon oluşturmaktadırlar (Tonguthai, 1997; Paperna ve Dzikowski, 2006). Cestodlar, endoparazitik helmintler olup heteroxene parazitlerdir. Balıklar son konak, paratenik konak ya da ara konak olabilmektedirler. Erişkin cestodlar sindirim sistemi kanalında bulunurken diğer gelişim dönemleri farklı organlara yerleşebilmektedir (Dick ve ark., 2006).

Parazitlerin balıklardaki enfeksiyon oranları; yaşam sikluslarına ve siklusta ara konak bulunup bulunmamasına, yaşadığı ortamın ekolojik özelliklerine, balıkların beslenme alışkanlıklarına, yaşlarına, boylarına, endo ve ektoparazit olarak yaşayan başka bir parazit ile enfekte olup olmamalarına göre değişiklik göstermektedir (Saygı, 1999). Tüm bunlar dikkate alındığında, parazitlerin olumsuz etkilerini azaltabilmek ve ekonomik kayıpları minumuma düşürebilmek için parazitlerin; türlerinin, konaklarının, yaşam sikluslarının, mevsimsel dağılım ve enfeksiyon oranlarının, yaş ve cinsiyete bağlı etkilerinin belirlenmesi önem arz etmektedir.

Dünyanın farklı coğrafik bölgelerinde yoğun bir şekilde yetiştiriciliği yapılan gökkuşağı alabalıklarında yürütülen çalışmalarda birçok metazoon ve protozoon türü tespit edilmiştir (Moravec, 2004; Saghari Fard ve ark., 2007; Atkinson ve Bartholomew, 2010; Skovgaard ve Buchmann, 2011; Rubio-Godoy ve ark., 2012). Türkiye'deki veriler değerlendirildiğinde ise çalışmaların daha çok ektoparazit protozoonlar üzerine olduğu, tüm paraziter faunayı belirlemeye, mevsimsel dağıIımlarını ortaya koymaya ve enfeksiyon oluşumunda etkili parametrelerin etki paylarının belirlenmesine yönelik çalışmalara çok fazla rastlanamamıştır (Ögüt ve Akyol, 2007; Altunay ve Yavuzcan Yıldız, 2008; Balta ve ark., 2008; Özer ve ark., 2010; Balta ve Balta, 2017). Gökkuşağı alabalıklarının metazoon parazit varlığı ve dağılımları hakkında sınırlı sayıda veri bulunmaktadır (Burgu ve ark., 1988; Sağlam, 2013; Avsever ve ark., 2016; Çevrimel ve Soylu, 2017; Balta ve Balta, 2018b). Metazoon parazit faunası ve mevsimsel dağılımları üzerine detaylı bir çalışma ise Pekmezci (2010) tarafından yapılmıştır.

Bu çalışmada, Aydın/Bozdoğan yöresinde yoğun bir şekilde yetiştiriciliği yapılan gökkuşağı alabalıklarında enfeksiyon oluşturan parazit türlerinin ve bunların aylara-mevsimlere göre dağılımlarının belirlenmesi, balık boy ve ağırlıklarının, su sıcaklığının, çözünmüş oksijen miktarının ve pH'nın enfeksiyon oluşumundaki olası etkilerinin ortaya konulması amaçlanmıştır.

\section{Gereç ve Yöntem}

\section{Araştırma sahası}

Adnan Menderes Üniversitesi Hayvan Deneyleri Yerel Etik Kurulu tarafından onaylanan (No:64583101/2013/055) bu çalışma, Eylül 2013Ağustos 2014 tarihleri arasında Aydın İli Bozdoğan İlçesi sınırları içerisinde yer alan Kemer Barajı $\left(37^{\circ}\right.$ $30^{\prime}$ Kuzey enlemi $28^{\circ} 35^{\prime}$ Doğu boylamı) ve Akçay üzerinde bulunan gökkuşağı alabalığı işletmelerinde 
Tablo 1. $4 \mathrm{~cm}^{2}$ 'lik alandan alınan kazıntıda tespit edilen parazitlerin enfeksiyon düzeylerine karşılık gelen enfeksiyon dereceleri

\begin{tabular}{lcc}
\hline Enfeksiyon Düzeylerinin Tanımlanması & Derecesi \\
\hline Enfeksiyon yok & 0 parazit & 0 \\
Düşük & $1-10$ parazit & 1 \\
Orta & $11-30$ parazit & 2 \\
Yüksek & $31-75$ parazit & 3 \\
Çok yüksek & $75<$ parazit & 4 \\
\hline
\end{tabular}

yürütülmüştür. Çalışma süresince iki adet havuz işletmesi 12 ay boyunca düzenli olarak ziyaret edilerek her işletmeden aylık 12 'şer adet balık numunesi olacak şekilde rastgele örneklem yapılmıştır. Barajdaki kafes işletmelerinde ise su sıcaklığına bağlı olarak yalnızca Aralık-Nisan ayları arasında üretim yapılabilmektedir. Bu sebeple kafes işletmesi toplam 5 ay boyunca ziyaret edilmiş ve aylık 12 'şer balık örneklenmiştir. Çalışma süresince havuz işletmelerinden 288, kafes işletmesinden ise 60 adet balık olmak üzere toplam 348 adet balık parazitolojik yönden incelenmiştir. Balıkların alındığı kafes veya havuzların sıcaklık $\left({ }^{\circ} \mathrm{C}\right), \mathrm{pH}$ ve oksijen değerleri $\left(\mathrm{O}_{2} \mathrm{mg} / \mathrm{L}\right)$ her ay dijital aletlerle (HANNA HI 9124 portable waterproof pH meters, HANNA HI 9142 portable waterproof dissolved oxygen meter) ölçülerek kaydedilmiştir.

\section{Balıkların laboratuvara taşınması ve paraziter muayene}

Balıklar havuz veya kafeslerden kepçe yardımıyla yakalanarak içerisinde ortam suyu bulunan taşıma kaplarıyla Adnan Menderes Üniversitesi Veteriner Fakültesi Parazitoloji Anabilim Dalı Laboratuvarına canlı olarak getirilmiştir. Paraziter yönden incelemeye başlamadan önce balıkların boyları ve ağırlıkları ölçülerek kaydedilmiştir. Ardından balıklar çıplak gözle ve stereo mikroskop altında incelenerek makroskobik muayeneleri tamamlanmış, varsa ektoparazitlerin veya lezyonların fotoğrafları çekilmiştir. Daha sonra ilgili literatürlere göre balıkların rutin parazitolojik muayeneleri ve nekropsileri gerçekleştirilmiştir (Lom ve Dyková, 1992; Buchmann ve Bresciani, 1997; Erer, ark., 2013) ilgili literatürlere göre yapılmıştır.

Parazitlerin enfeksiyon/enfestasyon oranı (\%) ve yoğunluğunun (adet) hesaplanması Bush ve ark (1997)'nın, enfeksiyon derecelerinin belirlenmesi ise Rintamiiki-Kinnunen ve Valtonen, (1997), Schisler ve ark., (1999), Jorgensen ve ark., (2009)'nın belirttiği şekilde yapılmıştır (Tablo 1).

\section{Istatistik analizler}

Su sıcaklığı $\left({ }^{\circ} \mathrm{C}\right)$, sudaki çözünmüş oksijen miktarı $\left(\mathrm{O}_{2} \mathrm{mg} / \mathrm{L}\right), \mathrm{pH}$, balık boy ve ağırlığının, enfeksiyon pozitif ve negatif gruplardaki farklılığının istatistik önem kontrolü Student T-testi ile; mevsimin enfeksiyon görülme oranı üzerine etkisinin istatistik önem kontrolü Ki-kare testi ile yapılmıştır. Enfeksiyon görülme olasılığı üzerine etkili olduğu düşünülen bazı parametrelerin (mevsim, su sıcaklığı, suda çözünmüş oksijen miktarı, pH, balık boy ve ağırlığı) etki paylarının belirlenmesi amacıyla da tek değişkenli lojistik regresyon analizi yapılmıştır. İstatistik analizlerde, SPSS 14:01 (SPSS Inc., Chicago, IL, USA) programı kullanılmıştır.

\section{Bulgular}

Aydın'ın Bozdoğan İlçesinde bulunan karasal işletmelerdeki havuzlardan ve Kemer Barajı'ndaki kafes işletmesinden farklı boy ve ağırlıkta toplam 348 adet gökkuşağı alabalığı örneklenerek paraziter açıdan incelenmiştir. İncelenen balıkların ortalama boy ve ağırlıkları Tablo 2'de verilmiştir.

Tablo 2. Karasal ve baraj işletmelerinden alınan balıkların boy $(\mathrm{cm})$ ve ağırlıkları $(\mathrm{g})$

\begin{tabular}{ccccc}
\hline & \multicolumn{3}{c}{ Balık } \\
\hline Boy & $\mathbf{N}$ & Minimum & Maksimum & $\bar{X} \pm S$ \\
\cline { 2 - 5 } Ăgılık & 348 & 15 & 36 & $24.12 \pm 4.86$ \\
\hline
\end{tabular}

N: Toplam incelenen balık sayısı $\bar{x} \pm S_{\bar{x}}$ : Ortalama \pm Standart hata

2002; Buchmann, 2007). Tespit edilen parazitlerin morfolojik tanımlamaları ve ölçümlerini gerçekleştirebilmek için fotoğraf ataçmanlı (Olympus DP70) araştırma mikroskobu (Olympus BX61WI marka) kullanımış ve teşhisleri (Lom ve Hoffman, 1964; Lom ve Dyková, 1992; Buchmann, 2007; Maceda Veiga ve
Enfeksiyonların seyrinde önemli olan su sıcaklığı ( $\left.{ }^{\circ} \mathrm{C}\right)$, sudaki çözünmüş oksijen miktarı $\left(\mathrm{O}_{2} \mathrm{mg} / \mathrm{L}\right)$ ve $\mathrm{pH}$ değerleri de düzenli olarak ölçülerek kaydedilmiştir. Çiftliklerde ölçülen en yüksek su sıcaklığı Eylül 2013 'te $25.1^{\circ} \mathrm{C}$ olarak, en düşük su sıcaklığı ise Ocak 2014 'te $9.6^{\circ} \mathrm{C}$ olarak belirlenmiştir. Sudaki en yüksek 
Tablo 3. Genel enfeksiyon oranının mevsimsel dağılımı

\begin{tabular}{|c|c|c|c|c|c|}
\hline \multirow[t]{3}{*}{ Mevsimler } & \multicolumn{4}{|c|}{ Enfeksiyon } & \multirow{3}{*}{$\begin{array}{c}\text { İncelenen } \\
\text { Balık } \\
\text { Sayı }\end{array}$} \\
\hline & \multicolumn{2}{|c|}{ Pozitif } & \multicolumn{2}{|c|}{ Negatif } & \\
\hline & Sayı & $\%$ & Sayı & $\%$ & \\
\hline Sonbahar & 39 & 54.2 & 33 & 45.8 & 72 \\
\hline Kış & 34 & 31.5 & 74 & 68.5 & 108 \\
\hline İlkbahar & 42 & 43.8 & 54 & 56.8 & 96 \\
\hline Yaz & 38 & 52.8 & 34 & 47.2 & 72 \\
\hline Toplam & 153 & 44 & 195 & 56 & 348 \\
\hline
\end{tabular}

Tablo 4. Balıkların boy $(\mathrm{cm})$ ve ağırlıklarının (g), genel enfeksiyon pozitif ve negatif gruplardaki farklılıkları

\begin{tabular}{lccccc}
\hline & \multicolumn{3}{c}{ Enfeksiyon } & İstatistik Önem \\
\cline { 2 - 5 } & $\mathbf{N}$ & Pozitif & Kogatif & $\begin{array}{c}\text { Kontrolü } \\
\text { (Student T test) }\end{array}$ \\
\hline Boy & 153 & $22.61 \pm 0.35$ & 195 & $25.31 \pm 0.35$ & $\mathrm{P}<0.01$ \\
Ağırlık & 153 & $142.76 \pm 0.62$ & 195 & $219.03 \pm 0.64$ & $\mathrm{P}<0.01$ \\
\hline
\end{tabular}

$N$ : Balık sayısı $\overline{\bar{X} \pm S_{\bar{x}}}$ : Ortalama \pm Standart hata

Tablo 5. Kafes ve havuzlardaki su sıcaklığının $\left({ }^{\circ} \mathrm{C}\right)$, çözünmüş oksijen miktarının $\left(\mathrm{O}_{2} \mathrm{mg} / \mathrm{L}\right)$ ve pH değerinin, genel enfeksiyon pozitif ve negatif gruplardaki farklılıkları

\begin{tabular}{|c|c|c|c|c|c|}
\hline \multirow{3}{*}{ Kafes ve Havuzlar } & \multicolumn{4}{|c|}{ Enfeksiyon } & \multirow[t]{3}{*}{$\begin{array}{c}\text { Istatistik Önem } \\
\text { Kontrolü } \\
\text { ( Student T test) }\end{array}$} \\
\hline & \multicolumn{2}{|c|}{ Pozitif } & \multicolumn{2}{|c|}{ Negatif } & \\
\hline & $\mathbf{N}$ & $\bar{X} \pm S_{x}$ & $\mathbf{N}$ & $\bar{X} \pm S_{x}$ & \\
\hline Sıcaklık & 153 & $17.14 \pm 0.3$ & 195 & $15.29 \pm 0.3$ & $P<0.01$ \\
\hline Oksijen & 153 & $6.7 \pm 0.09$ & 195 & $6.9 \pm 0.09$ & $P<0.05$ \\
\hline $\mathrm{pH}$ & 153 & $7.98 \pm 0.02$ & 195 & $7.94 \pm 0.02$ & $P>0.05$ \\
\hline
\end{tabular}

\section{N: Balık sayısı $\overline{\bar{X} \pm S_{\bar{x}}}:$ Ortalama \pm Standart hata}

çözünmüş oksijen miktarı, $9.3 \mathrm{mg} / \mathrm{L}$ olarak Ocak 2014 'te, en düşük 4.9 mg/L olarak Haziran 2014'te ölçülmüştür. pH'nın ise yıl boyunca 7.3 ile 8.3 arasında değiştiği görülmüştür.

İncelenen 348 adet balığın 153'ünün (\%44) çeşitli parazitlerle enfekte olduğu görülmüştür. Tespit edilen parazitlerin 3'ü protozoon olup, Ciliatalar şubesinin Oligohymenophorea sınıfında, 1 'i ise metazoon olup, Arthropoda şubesinin Maxillapoda sınıfında yer almaktadır. İncelenen balıkların; 118'i (\%33.9) Trichodina fultoni, 19'u (\%5.4) Ichthyophthirius multifiliis, $5^{\prime} \mathrm{i}$ (\%1.4) Apiosoma sp., 4'ü (\%1.1) Lernaea sp., olmak üzere tek türle enfekte iken, 7 'sinde (\%2) miks enfeksiyon tespit edilmiştir. Miks enfeksiyon tespit edilen balıkların 5'inin (\%1.4) T. fultoni + I. multifiliis; 2 'sinin $(\% 0.6)$ ise $T$. fultoni + Apiosoma sp. ile enfekte olduğu belirlenmiştir.
Örneklenen balıklarda her mevsim parazite rastlanmıştır. Genel enfeksiyon oranının mevsimsel dağılımı farklılık göstermiş olup (Tablo 3), istatistiksel olarak önemli bulunmuştur $(\mathrm{P}<0.01)$.

Balık boy ve ağırlıklarının, genel enfeksiyon pozitif ve negatif gruplardaki farklılıkları değerlendirildiğinde istatistiksel olarak önemli olduğu görülmüştür $(P<0.01)$. Buna göre, boyları kısa ve ağırlıkları düşük olan balıklarda paraziter enfeksiyonlar daha yoğun tespit edilmiştir (Tablo 4).

Diğer önemli parametreler olan su sıcaklığı ve çözünmüş oksijen miktarının, genel enfeksiyon pozitif ve negatif gruplardaki farklılıkları istatistiksel olarak önemli bulunurken, pH'nın ( $P>0.05)$ önemli olmadığı saptanmıştır. Buna göre, enfeksiyon tespit edilen su sıcaklığının daha yüksek olduğu belirlenirken, su sıcaklığıyla ters orantılı olan çözünmüş oksijen mikta- 
rının ise daha düşük olduğu saptanmıştır (Tablo 5).

İncelenen balıkların 125 'inde (\%35.9) (miks enfeksiyonlar dahil) Trichodina enfeksiyonu tespit edilmiş, ilgili literatürlere göre yapılan morfolojik analizler sonucunda etken $T$. fultoni olarak identifiye edilmiştir. Etkenin enfeksiyon oranı (\%) ve enfeksiyon derecelerinin aylara göre dağılımı incelendiğinde Ocak ayı hariç diğer tüm aylarda farklı enfeksiyon derecelerinde enfeksiyona rastlanmıştır. En yüksek enfeksiyon oranı Kasım ayında \%75 (18/24) oranında belirlenirken, bunu \%62.5 (15/24) ile Haziran ayı takip etmiştir. En düşük enfeksiyon oranı ise \%12.5 (3/24) ile Eylül ayında tespit edilmiştir. Diğer aylardaki enfeksiyon oranları ise \%16.6 ile \%47.2 arasında değişiklik göstermiştir. Eylül, Aralık, Şubat ve Ağustos aylarında düşük enfeksiyon derecesi (1) belirlenirken, enfeksiyonun görüldüğü diğer aylarda ise orta şiddette (2) enfeksiyonlar görülmüştür (Şekil 1).

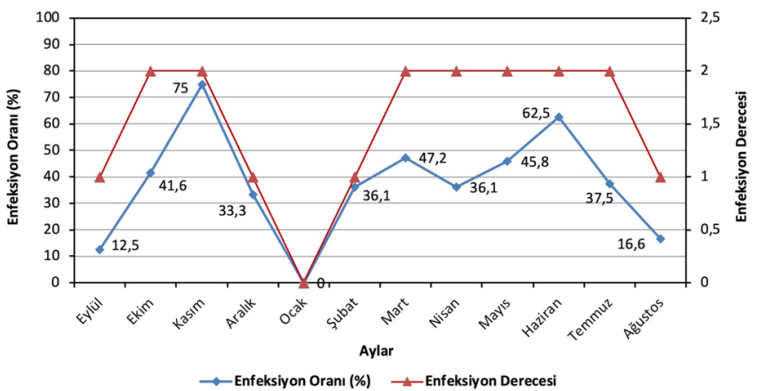

Şekil 1. Trichodina fultoni'nin enfeksiyon oranı (\%) ve enfeksiyon derecelerinin aylara göre dağılımı

Trichodina fultoni enfeksiyonuna her mevsim rastlanmış olup mevsimsel dağılımı farklılık göstermiştir $(P<0.05)$. En yüksek enfeksiyon oranı [(\%43.1), 31/72] sonbahar mevsiminde tespit edilirken, en düşük [(\%23.1), 25/108] kış mevsiminde saptanmıştır. İlkbahar ve yaz mevsimindeki enfeksiyon oranı ise sırasıyla \%42.7 (41/96); \%38.9 (28/72) olarak belirlenmiştir. Balık boy ve ağırlıklarının, enfeksiyon pozitif ve negatif gruplardaki farklılıkları da istatistiksel olarak önemli bulunmus olup enfeksiyon tespit edilen balıkların boylarının daha kısa, ağırlıklarının ise daha düşük olduğu belirlemiştir (Tablo 6).
Yine su sıcaklığı ve sudaki çözünmüş oksijen miktarının, $T$. fultoni pozitif ve negatif gruplardaki farklılıkları istatistiksel olarak önemli bulunurken, pH'nın ( $P>0.05)$ önemli olmadığı görülmüştür. Buna göre $T$. fultoni enfeksiyonu tespit edilen su sıcaklığının daha yüksek olduğu, su sıcaklığıyla ters orantılı olan çözünmüş oksijen miktarının ise daha düşük olduğu saptanmıştır (Tablo 7).

Çalışma süresince balıklarda tespit edilen bir diğer protozoon olan I. multifiliis'in enfeksiyon oranı \%6.9 (24/348) (miks enfeksiyonlar dahil) olarak belirlenmiştir. Etkenin enfeksiyon oranı (\%) ve enfeksiyon derecelerinin aylara göre dağılımı incelendiğinde toplam beş ay enfeksiyona rastlanmıştır. En yüksek enfeksiyon oranı [(\%33.3), 8/24] Ağustos ayında tespit edilirken bunu Kasım [(\%29.1), 7/24] ve Eylül [(\%20.8), 5/24] ayları takip etmiştir. En düşük enfeksiyon oranı ise Nisan [(\%5.5), 2/36] ayında belirlenmiştir. En yüksek enfeksiyon derecesi (3) Eylül ayında belirlenirken, en düşük (1) Nisan ayında belirlenmiştir. Enfeksiyonun görüldüğü diğer aylarda ise orta (2) enfeksiyon derecesi saptanmıştır (Şekil 2)

Ichthyophthirius multifiliis enfeksiyonuna kış mevsimi haricindeki mevsimlerde rastlanmıştır. Enfeksiyonunun mevsimsel dağılımı farklılık göstermiş olup, istatistiksel olarak önemli bulunmuştur $(P<0.01)$. En yüksek enfeksiyon oranı [(\%16.7), 12/72] sonbahar mevsiminde tespit edilirken, en düşük ilkbahar mevsiminde [(\%2.1), 2/96] belirlenmiştir. Yaz mevsiminde ise \%13.9 (10/72) olarak hesaplanmıştır. Trichodina enfeksiyonunda olduğu gibi balık boy/ağırlıklarının, su sıcaklığının ve sudaki çözünmüş oksijen miktarının, I. multifiliis pozitif ve negatif gruplardaki farklılıkları istatistiksel olarak önemli bulunmuştur (Tablo 8 ve 9).

Çalışmada tespit edilen bir diğer protozoon olan Apiosoma sp.'nin enfeksiyon oranı \%2 (7/348) (miks enfeksiyonlar dahil) olarak belirlenmiştir. Bu protozoona sadece Ocak ve Şubat aylarında rastlanmıştır. Ocak ayında enfeksiyon oranı \%5.55 (2/36) iken Şubat ayında ise \%8.33 (3/36) olarak hesaplanmıştır. Enfeksiyon derecesi Ocak ayında orta (2) olarak tespit edilirken, Şubat ayında ise yüksek (3) olarak belirlenmiştir.

Çalışma boyunca tespit edilen protozoonların enfeksiyon düzeylerine karşılık gelen enfeksiyon derecelerinin dağııımı ise Tablo 10'da verilmiştir.

Tablo 6. Balık boy (cm) ve ağırlıklarının (g), T. fultoni pozitif ve negatif gruplardaki farklılıkları

\begin{tabular}{lccccc}
\hline & \multicolumn{3}{c}{ Enfeksiyon } & Istatistik önem \\
\cline { 2 - 5 } & $\mathbf{N}$ & Pozitif & $\mathbf{N}$ & Negatif & $\begin{array}{c}\text { Kontrolü } \\
\text { (Student T test) }\end{array}$ \\
\hline Boy & 125 & $\overline{\boldsymbol{X}} \pm \boldsymbol{S}_{\boldsymbol{x}}$ & $\mathbf{N}$ & $\overline{\boldsymbol{X}} \pm \boldsymbol{S}_{\boldsymbol{X}}$ & $\mathrm{P}<0.001$ \\
Ağırlık & 125 & $148.03 \pm 7.16$ & 223 & $24.87 \pm 0.33$ & $\mathrm{P}<0.001$ \\
\hline
\end{tabular}

$N$ : Balık sayısı $\bar{X} \pm S_{\bar{x}}$ : Ortalama \pm Standart hata 
Tablo 7. Kafes ve havuzlardaki su sıcaklığının $\left({ }^{\circ} \mathrm{C}\right)$, çözünmüş oksijen miktarının $\left(\mathrm{O}_{2} \mathrm{mg} / \mathrm{L}\right)$ ve $\mathrm{pH}$ değerinin $T$. fultoni pozitif ve negatif gruplardaki farklılıkları

\begin{tabular}{|c|c|c|c|c|c|}
\hline \multirow{3}{*}{ Kafes ve Havuzlar } & \multicolumn{4}{|c|}{ Enfeksiyon } & \multirow{3}{*}{$\begin{array}{l}\text { İstatistik Önem } \\
\text { Kontrolü } \\
\text { (Student T test) }\end{array}$} \\
\hline & \multicolumn{2}{|c|}{ Pozitif } & \multicolumn{2}{|c|}{ Negatif } & \\
\hline & $\mathbf{N}$ & $\bar{X} \pm S_{x}$ & $\mathbf{N}$ & $\bar{X} \pm S_{x}$ & \\
\hline Sıcaklık & 125 & $16.75 \pm 0.30$ & 223 & $15.74 \pm 0.30$ & $P<0.05$ \\
\hline Oksijen & 125 & $6.61 \pm 0.1$ & 223 & $7.00 \pm 0.08$ & $P<0.01$ \\
\hline $\mathrm{pH}$ & 125 & $7.98 \pm 0.03$ & 223 & $7.95 \pm 0.02$ & $P>0.05$ \\
\hline
\end{tabular}

N: Balık sayısı $\overline{\bar{X} \pm S_{\bar{x}}}:$ Ortalama \pm Standart hata

Tablo 8. Balık boy ve ağırlıklarının, I. multifiliis pozitif ve negatif gruplardaki farklııkları

\begin{tabular}{lccccc}
\hline & \multicolumn{3}{c}{ Enfeksiyon } & Istatistik önem \\
\cline { 2 - 4 } & $\mathbf{N}$ & Pozitif & Negatif & $\begin{array}{c}\text { Kontrolü } \\
\text { (Student T test) }\end{array}$ \\
\cline { 2 - 5 } & 24 & $\bar{X} \pm S_{\mathbf{x}}$ & $\mathbf{N}$ & $\bar{X} \pm S_{x}$ & $\mathrm{P}<0.01$ \\
Aog (cm) & $21.46 \pm 0.85$ & 324 & $24.32 \pm 0.27$ & $\mathrm{P}<0.001$ \\
\hline
\end{tabular}

N: Balık sayısı $\bar{X} \pm S_{g}$ : Ortalama \pm Standart hata

Tablo 9. Kafes ve havuzlardaki su sıcaklığının $\left({ }^{\circ} \mathrm{C}\right)$, çözünmüş oksijen miktarının $\left(\mathrm{O}_{2} \mathrm{mg} / \mathrm{L}\right)$ ve pH değerinin, I. multifiliis pozitif ve negatif gruplardaki farklılıkları

\begin{tabular}{|c|c|c|c|c|c|}
\hline \multirow{3}{*}{ Kafes ve Havuzlar } & \multicolumn{4}{|c|}{ Enfeksiyon } & \multirow{3}{*}{$\begin{array}{l}\text { İstatistik Önem } \\
\text { Kontrolü } \\
\text { (Student T test) }\end{array}$} \\
\hline & \multicolumn{2}{|c|}{ Pozitif } & \multicolumn{2}{|c|}{ Negatif } & \\
\hline & $\mathbf{N}$ & $\bar{X} \pm S_{x}$ & $\overline{\mathbf{N}}$ & $\bar{X} \pm S_{X}$ & \\
\hline Sıcaklık & 24 & $20.33 \pm 0.76$ & 324 & $15.79 \pm 0.22$ & $P<0.001$ \\
\hline Oksijen & 24 & $6.33 \pm 0.07$ & 324 & $6.9 \pm 0.15$ & $P<0.05$ \\
\hline $\mathrm{pH}$ & 24 & 8.00 & 324 & $7.96 \pm 0.01$ & $P>0.05$ \\
\hline
\end{tabular}

N: Balık sayısı $\overline{\bar{X} \pm S_{\bar{X}}}:$ Ortalama \pm Standart hata

Tablo 10. Tespit edilen protozoonların enfeksiyon derecelerinin dağılımı

\begin{tabular}{lcccccc}
\hline Enfeksiyon & \multicolumn{2}{c}{ T. fultoni } & \multicolumn{2}{c}{ I. multifiliis } & \multicolumn{2}{c}{ Apiosoma sp. } \\
\cline { 2 - 7 } Dereceleri & Sayı & \% & Sayı & \% & Sayı & \% \\
\hline Düşük (1) & 53 & 15.2 & 4 & 1.1 & 1 & 0.2 \\
Orta (2) & 62 & 17.8 & 15 & 4.3 & 3 & 0.9 \\
Yüksek (3) & 10 & 2.9 & 5 & 1.4 & 3 & 0.9 \\
Toplam & 125 & 35.6 & 24 & 6.8 & 7 & 2 \\
\hline
\end{tabular}

Çalışmada bulunan tek metazoon olan Lernaea sp. ile enfeste balık oranı ise \%1.1 (4/348) olarak belirlenmiş olup enfestasyona yalnızca Ocak ayında rastlanmıştır. Balıklar üzerinden toplam 32 adet Lernaea sp. toplanmış ve enfestasyon yoğunluğu 8 olarak belirlenmiştir. Balıkların makroskobik muayeneleri esnasında parazitlerin tutundukları vücut yüzeylerin- de ödem ve yara izlerine rastlanmış olup, meydana gelen lezyonların çapının 5-9 mm arasında olduğu görülmüştür. Yapılan mikroskobik incelemeler sonucunda etkenlerin olgunlaşmış ve iki adet yumurta kesesine sahip dişi Lernaea sp. ler oldukları belirlenmiştir. 


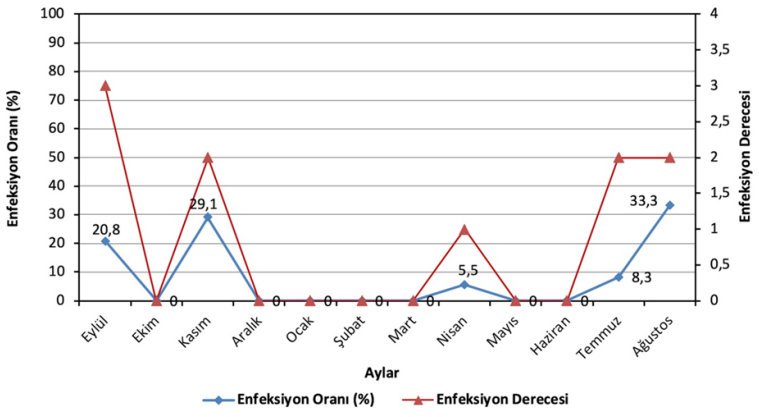

Şekil 2. Ichthyophthirius multifiliis'in enfeksiyon oranı (\%) ve enfeksiyon derecelerinin aylara göre dağılımı

\section{Tek değişkenli lojistik regresyon modelleri}

Mevsim, balık boy ve ağırlıkları, su sıcaklığı, sudaki çözünmüş oksijen miktarı ve pH modele dahil edilmiştir. Parazitlerin görülme oranları ve mevsimsel dağılımları arasındaki ilişkinin istatistiksel olarak önemli olduğu görülmüştür. Tek değişkenli lojistik

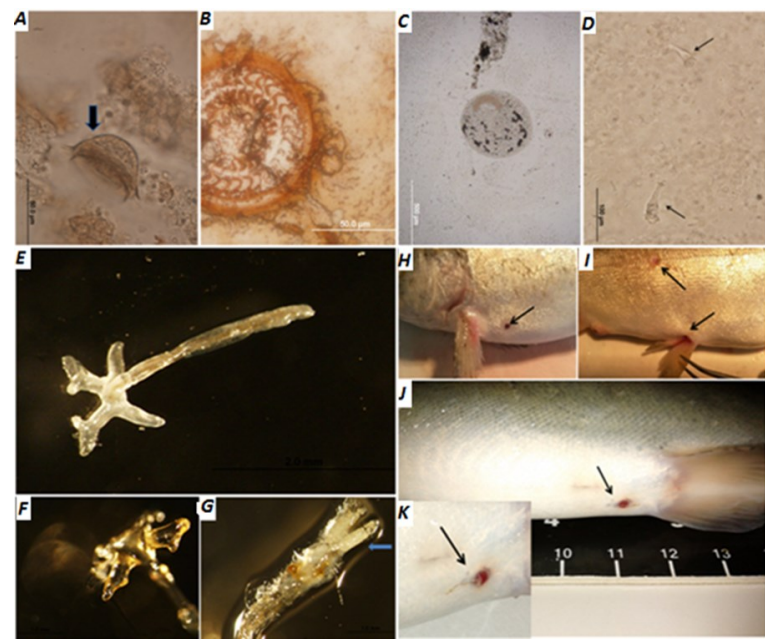

Şekil 3. A) Trichodina sp. B) T. fultoni (gümüş nitrat boyama) C) Ichthyophthirius multifiliis (trofont) D) Apiosoma sp. E-K) Lernaea sp. F-G) Baş ve kuyruk kısmı, G) Yumurta keseleri H-K). Konak üzerinde oluşturduğu lezyonlar

Tablo 11. Tek değişkenli lojistik regresyon modelleri

\begin{tabular}{|c|c|c|c|c|c|c|c|c|}
\hline \multirow{4}{*}{$\begin{array}{l}\text { Değişken } \\
\text { Mevsim }\end{array}$} & \multirow{2}{*}{$\begin{array}{c}\begin{array}{c}\text { Değişken } \\
\text { Sınırları }\end{array} \\
\text { Yaz } \\
\text { (Referans) }\end{array}$} & \multirow[t]{2}{*}{$\widehat{\boldsymbol{\beta}}$} & \multirow[t]{2}{*}{$\operatorname{SE}(\widehat{\beta})$} & \multirow{2}{*}{$\begin{array}{l}\text { Wald } \\
11.907\end{array}$} & \multirow{2}{*}{$\begin{array}{r}\text { P Değeri } \\
0.008\end{array}$} & \multirow[t]{2}{*}{ OR } & \multicolumn{2}{|c|}{$\begin{array}{c}\text { OR'nin \%95 } \\
\text { Güven Aralığı }\end{array}$} \\
\hline & & & & & & & & \\
\hline & Sonbahar & 0.056 & 0.334 & 0.028 & 0.867 & 1.057 & 0.549 & 2.036 \\
\hline & KIŞ & -0.889 & 0.314 & 8.010 & 0.005 & 0.411 & 0.222 & 0.761 \\
\hline & İlkbahar & -0.363 & 0.313 & 1.340 & 0.247 & 0.696 & 0.377 & 1.286 \\
\hline & Sabit & 0.111 & 0.236 & 0.222 & 0.638 & 1.118 & & \\
\hline \multirow{3}{*}{ Boy } & Boy & -0.121 & 0.024 & 25.167 & $<0.001$ & 0.886 & 0.845 & 0.929 \\
\hline & Sabit & 2.665 & 0.586 & 20.663 & $<0.001$ & 14.375 & & \\
\hline & Ağırlık & -0.010 & 0.001 & 50.726 & $<0.001$ & 0.990 & 0.987 & 0.992 \\
\hline Ağırlık & Sabit & 1.633 & 0.279 & 34.118 & $<0.001$ & 5.117 & & \\
\hline \multirow{2}{*}{ Sıcaklık } & Sıcaklık & 0.110 & 0.027 & 16.460 & $<0.001$ & 1.116 & 1.059 & 1.177 \\
\hline & Sabit & -2.025 & 0.455 & 19.811 & $<0.001$ & 0.132 & & \\
\hline \multirow{2}{*}{ Oksijen } & Oksijen & -0.172 & 0.086 & 4.040 & 0.044 & 0.842 & 0.712 & 0.996 \\
\hline & Sabit & 0.936 & 0.595 & 2.477 & 0.115 & 2.551 & & \\
\hline \multirow{2}{*}{ pH } & $\mathrm{pH}$ & 0.380 & 0.345 & 1.210 & 0.271 & 1.462 & 0.743 & 2.877 \\
\hline & Sabit & -3.270 & 2.755 & 1.409 & 0.235 & 0.038 & & \\
\hline
\end{tabular}

$\widehat{\widehat{\beta}}$ : Kestirilen eğim katsayısı, SE( $\widehat{\widehat{\beta}}$ ): Kestirilen eğim katsayısının standart hatası, Wald: Model için eğim katsayılarııı sıfıra eşit olup olmadığını test eden Wald istatistiği, P: Wald istatistiğine ait $P$ değeri, OR: Kestirilen odds oranı

regresyon analizi sonucuna göre kış mevsiminde enfeksiyon görülme oranının yaza göre 0.41 kat daha az olduğu ortaya konmuştur. Balık boy ve ağırlıklarının, genel enfeksiyon pozitif ve negatif gruplardaki farklılıkları istatistiksel olarak önemli bulunmuştur. Boydaki bir birimlik (cm) artış, enfeksiyonun odds oranını (OR) 0.88 kat azaltırken, ağırlıktaki bir birimlik (g) artışın ise 0.99 kat azalttığı görülmüştür. Su parametrelerinin, genel enfeksiyon pozitif ve negatif gruplardaki farklılıkları değerlendirildiğinde ise; su sıcaklığı ve çözünmüş oksijen miktarı istatistiksel olarak önemli bulunurken, pH'nın önemli olmadığı görülmüş- 
tür. Buna göre sıcaklıktaki bir birimlik $\left({ }^{\circ} \mathrm{C}\right)$ artış enfeksiyonun odds oranını (OR) 1.116 kat artıırken, çözünmüş oksijen miktarındaki bir birimlik artışın $\left(\mathrm{O}_{2}\right.$ $\mathrm{mg} / \mathrm{L}$ ) ise 0.842 kat azalttığı görülmüştür (Tablo 11).

\section{Tartışma ve Sonuç}

Türkiye'de gökkuşağı alabalığı yetiştiriciliği her geçen gün artmakta ve ülke ekonomisine oldukça büyük katkı sağlamaktadır. Ancak, entansif yetiştiricilik koşullarında üretimi yapılan balıklar, doğal ortamda bulunanlara göre çok daha fazla strese maruz kalmakta ve enfeksiyonlara (paraziter, bakteriyel ve viral) açık hale gelmektedirler. Hastalık kaynaklı ölümlere ve tedavi giderlerine bağlı olarak da ciddi ekonomik kayıplar yaşanmaktadır. Bu kayıpların en aza indirilebilmesi için balıkların önemli patojenlerinden olan paraziter etkenlerin yaygınlıklarının ve mevsimsel dağılımlarının belirlenmesi ayrıca hastalık oluşumunda etkili parametrelerin etki paylarının değerlendirilmesi gerekmektedir. Bu bağlamda, Aydın/ Bozdoğan yöresinde yetiştirilen gökkuşağı alabalıklarında paraziter yaygınlığı belirlenmeyi ve bazı parametrelerin hastalık oluşumu üzerindeki etkilerini ortaya koymayı amaçlayan çalışma kapsamında toplam 348 adet balık incelenmiş ve 153'ünün (\%44) çeşitli parazitlerle enfekte olduğu tespit edilmiştir. Türkiye ve dünyanın farklı coğrafik bölgelerinde gökkuşağı alabalıklarında yapılan bazı çalışmalarda paraziter enfeksiyonların genel prevalansı \%18.14 ila \%90 arasında rapor edilmiştir (Schisler ve ark., 1999; Altunay ve Yavuzcan Yıldız, 2008; Özer ve ark., 2010; Poulin ve ark., 2012). Paraziter enfeksiyonların prevalanslarındaki bu geniş aralık ise hastalık oluşumunda etkili olan çevre ve yetiştiricilik koşullarının çalışmanın yapıldığı coğrafik alana göre farklılık gösterebilmesine bağlanmaktadır.

Çalışma süresince incelenen balıkların; 118'i (\%33.9) T. fultoni, 19'u (\%5.4) l. multifiliis, $5^{\prime} \mathrm{i}$ (\%1.4) Apiosoma sp., 4'ü (\%1.1) Lernaea sp., olmak üzere tek türle enfekte iken, 7 tanesinde (\%2) T. fultoni+ I. multifiliis (\%1.4); T. fultoni+Apiosoma sp. $(\% 0.6)$ 'den kaynaklanan miks enfeksiyonlar tespit edilmiştir. Türkiye'de gökkuşağı alabalıklarında yapıIan çalışmalarda Trichodina spp., I. multifiliis, Apiosoma sp., I. necator, Chilodonella spp., Epistylis sp., Costia sp. Spironucleus salmonis ve Hexamita salmonis gibi protozoonlar rapor edilmişlerdir. Balıklarda sıklıkla karşılaşılan Trichodina spp.'nin prevalansı \%1.8-85 arasında, I. multifiliis'in prevalansı ise \%5.88-20.69 arasında bildirilmiştir (Balta ve ark., 2008; Altunay ve Yavuzcan Yıldız, 2008; Özer ve ark., 2010; Çevrimel ve Soylu, 2017; Diler ve ark., 2018; Balta ve Balta, 2018a). Özer ve ark., (2010)'। miks enfeksiyonu sadece bir balıkta (Trichodina spp.+Chilodonella spp.) rastladıklarını belirtirken, Altunay ve Yavuzcan Yıldız, (2008) ise iki etkenle enfekte balık oranının \%66.6 olduğu bildirmiştir. İran'da gökkuşağı alabalıklarında yapılan çalışmada ise I. multifiliis, Trichodina sp., Chilodonella sp. tespit edilmiş olup prevalansları sırasıyla \%16.4; 14 ; 1 olarak belirlenmiştir (Poulin ve ark., 2012). Yine Danimarka'da yapılan farklı çalışmalarda tespit edilen bir çok parazitin arasında Trichodina sp., Apisoma sp., I. multifiliis, T. fultoni türlerinin yer aldığı dikkat çekmiştir. (Buchmann ve Bresciani, 1997; Jørgensen ve ark., 2009). Çalışmalarda genellikle Trichodina sp.'nin baskın protozoon olduğu ve prevalansının yüksek olduğu görülmekte ve mevcut çalışmanın bulgularıyla benzerlik göstermektedir. Ayrıca çalışma süresince Trichodina' nın her mevsim enfeksiyon oluşturabilmesi ve yapılan bir çok çalışmada da tespit edilmiş olması, bu etkenin gökkuşağı alabalığı işletmeleri için her zaman bir tehdit unsuru olabileceğini ortaya koymaktadır. Fırsatçı parazitler, her ne kadar konak üzerinde sayıları az olduğu dönemlerde ciddi enfeksiyonlar oluşturmasalar da, küresel ısınmanın gündemde olduğu son yıllarda su sıcaklıklarındaki değişikliklere bağlı olarak ortaya çıkan stres faktörleri sonucu söz konusu parazitlerin her zaman enfeksiyon oluşturabileceği intimali göz önünde bulundurulmalıdır. Yine bu gibi olumsuz koşulların yanı sıra daha fazla kar amaçlayan işletmelerde stok yoğunluğunun arttırılması ve aşırı yemleme gibi bilinçsiz yapılan yetiştiricilik uygulamaları sonucu, sularda biriken yem ve metabolizma atıkları, su kalitesinin bozulmasına ve sonuç olarak balıkların strese girmelerine sebep olmaktadır. Balıkların immun sistemlerinin zayıflamasına neden olan bu gibi durumlar fırsatçı parazitlere zemin hazırlamakta ve işletmeler için her zaman bir risk oluşturmaktadır (Karasev ve ark., 199; Durborow, 2003; Karvonen ve ark., 2010). Yine bu çalışmada I. multifiliis prevalansının diğer çalışmalara göre daha düşük olmasının sebebi su sıcaklığına bağlanmıştır. Nitekim Aihua ve Buchmann, (2001) bu protozoonun yaşam siklusuyla su sıcaklığı arasında pozitif bir korelasyonun bulunduğunu vurgulamıştır. Çalışmanın yapıldığı yörenin, sıcak bir bölgede yer alması, su sıcaklığının yaz aylarında yetiştiricilik koşullarının oldukça dışına çıkmasına sebep olmaktadır. Bu durum göz önünde bulundurulduğunda I. multifiliis prevalansının oldukça yüksek olması beklenmektedir. Ancak, artan su sıcaklığına önlem olarak yaz mevsiminde barajdaki kafes işletmelerinde üretim durdurulmaktadır. Üretime ise daha düşük su sıcaklığına sahip baraj dip suyunun aktarıldığı karasal işletmelerde devam edilmektedir. Bu uygulamanın yetersiz kaldığı durumlarda ise havuzlar yer altı sularıyla desteklenerek su sıcaklığının bazı işletmelerde aşırı yükselmesi engellenebilmektedir. Böylelikle, özellikle su sıcaklığının ayarlanabildiği işletmelerde I. multifiliis'e daha az rastlanmakta ve buna bağlı olarak da parazitin genel prevalansı düşük olmaktadır. Nitekim çalışma süresince su sıcaklığındaki değişimlerin hastalık oluşumunda etkisi istatistikî olarak önemli bulunmuştur $(\mathrm{P}<0.01)$.

Çalışma boyunca balıklarda en yaygın olarak rastla- 
nan protozoon türünün $T$. fultoni olduğu görülmüştür. Bu protozoon Ocak ayı haricindeki diğer aylarda farklı enfeksiyon oranları ve enfeksiyon derecelerinde tespit edilmiştir. Buchmann ve Bresciani, (1997) yaptıkları çalışmada Trichodina türleri tarafından oluşturulan enfeksiyonunun Mayıs, Haziran ve Eylül ayları hariç yıl boyunca görüldüğünü bildirmişlerdir. Jorgensen ve ark. (2009) Danimarka'da resirkülatif sistemin kurulu olduğu çiftliklerden örneklediği gökkuşağı alabalıklarında, Eylül, Aralık ve Nisan ayları haricinde Trichodina sp. enfeksiyonuna rastladıklarını rapor etmişlerdir. Altunay ve Yavuzcan Yıldız, (2008) ise Trichodina sp. enfeksiyonunu yıl boyunca \%100'e varan enfeksiyon oranlarında tespit etmişlerdir. Yine Balta ve ark., (2008) Trichodina sp.'ye Mayıs-Eylül ayları arasında rastladıklarını ve en yüksek enfeksiyon oranının Ağustos ayında tespit edildiğini belirtmişlerdir. Yaptığımız çalışmada ise balıklarda bir ay hariç yıl boyunca bulunan bu etkenin en yüksek enfeksiyon oranı Kasım (\%75) ayında tespit edilmiş olup, diğer çalışmalarla farklılık göstermektedir. Enfeksiyon oranının özellikle bu ayda artmasının sebebi; Kasım ayı Bozdoğan yöresinde baraj suyunun yetiştiriciliğe uygun olmaya başladığı ay olup, balıkların bir kısmı barajdaki ağ kafeslere aktarılmaktadır. $\mathrm{Bu}$ nedenle hem su sıcaklığının uygun olması hem de balıkların pazara daha erken sürülebilmesi için karasal işletmelerde yoğun bir yemleme süreci başlamaktadır. Bu durum balıkların metabolizmasının hızlanmasına aynı zamanda aşırı su kirliliğine de sebep olarak balıklar üzerinde bir stres faktörü oluşturabilmektedir. Sonuç olarak strese bağlı immun sistemleri etkilenen balıkların bu gibi fırsatçı paraziter enfeksiyonlara yakalanması kaçınılmaz olmaktadır. Nitekim Karasev ve ark. (1997)'nın yaptıkları çalışmada, Trichodina nigra'nın üreme ve çoğalmasında özellikle su sıcaklığı ve suda artan organik madde miktarının oldukça önemli olduğu belirtilmiştir.

Çalışma süresince tespit edilen diğer önemli bir protozoon I. multifiliis türüdür. Balta ve ark. (2008) yaptıkları çalışmada Mayıs'tan Eylüle kadar olan dönemde bu enfeksiyonun tespit edildiğini ve en yüksek prevalans oranına Ağustos ayında ulaştığını bildirirken, Buchmann ve Bresciani, (1997) I. multifiliis'in tipik olarak termofilik bir protozoon olduğunu ve Aralık'tan Haziran'a kadar olan dönemde herhangi bir enfeksiyon oluşturmadığını rapor etmişlerdir. En yüksek enfeksiyon oranına ise (\%10-20 mortalite) Temmuz-Eylül ayları arasındaki dönemde ulaştığını, daha sonra azalarak Kasım'a kadar devam ettiğini belirtmişlerdir. Hastalığın, Temmuz'da \%11, Ağustos'ta \% 23, Eylül'de \%14, Ekim'de \%4 ve Kasım'da \%2'lik bir prevalansla seyrettiğini ortaya koymuşlardır. Özer ve ark. (2010) yaptıkları çalışmada ise ilkbaharda $I$. multifiliis'e rastlanmazken diğer aylarda baskın tür olduğunu rapor etmişlerdir. Öğüt ve ark. (2005) Karadenizde $I$. multifiliis'in mevsimsel olarak dağılımını inceledikleri bir çalışmada enfeksiyonun en yüksek prevalans, ortalama yoğunluk ve bolluk değerlerine Ağustos ayında ulaştığını ve kış mevsiminde enfeksiyon tespit edemediklerini belirtmişlerdir. Yaptığımız çalışmada I. multifiliis enfeksiyonuna toplam beş ay rastlanmış olup en yüksek enfeksiyon oranı Ağustos (\%33.3) ayında belirlenirken, bunu Kasım (\%29.1) ayı takip etmiştir. En düşük enfeksiyon oranı ise Nisan (\%5.5) ayında tespit edilmiştir. Diğer çalışmalarla benzer olarak, mevcut çalışmada I. multifiliis enfeksiyonunun genellikle su sıcaklığının yüksek olduğu aylarda tespit edildiği ve prevalansının Ağustos ayında pik yaptığı belirlenmiştir. Ayrıca I. multifiliis enfeksiyonu kış mevsimi haricindeki tüm mevsimlerde farkIı enfeksiyon oranlarında tespit edilmiş olup, bu farklılık istatistiki olarak önemli bulunmuştur. Bu protozoonun üreme ve çoğalmasında su sıcaklığı önem arz etmektedir. Bu nedenle yaz mevsiminde ve erken sonbahar döneminde bu protozoona daha sık rastlanmaktadır. Dickerson, (2006)'nun belirttiğine göre yaşam siklusundaki evreler ancak su sıcaklığının 21$23^{\circ} C^{\prime}$ ye ulaştığı dönemlerde tamamlanabilmektedir. Eğer ortam sıcaklığı $10^{\circ} \mathrm{C}$ 'nin altındaysa kistlenme meydana gelmemekte ve bölünme şekillenmemektedir. Bu durum enfeksiyonun kış mevsiminde görülmemesinin sebebini açıkça ortaya koymaktadır. I. multifiliis enfeksiyonu üzerine su parametrelerindeki değişimlerin etkisi değerlendirildiğinde; Öğüt ve ark. (2005) yaptıkları çalışmada su sıcaklığıyla ortalama yoğunluk arasında önemli bir ilişki bulunduğunu, ayrıca logaritmik bir artışın söz konusu olduğunu belirtmişlerdir. Su sıcaklığının $18^{\circ} \mathrm{C}$ 'nin üzerine çıktığı dönemlerde konak üzerinde parazit sayısının arttığını ve prevalansının \%80'nin üzerine çıktığını vurgulamışlardır. Enfeksiyonun geç yaz döneminde meydana gelmesinin sebebini ise, su sıcaklığının yüksek olması, yağış miktarının az olmasına bağlı olarak su seviyesinin düşük olması ve gece-gündüz arasındaki su sıcaklık farkının az olması gibi yetiştiriciliği olumsuz etkileyebilecek koşullarla açıklamışlardır. Yine Buchmann ve Bresciani, (1997) bu etkenin prevalansının en yüksek olduğu sıcaklık aralığını $16-20^{\circ} \mathrm{C}$ olarak belirlemiş olup, sıcaklık arttıkça prevalansının arttığını bildirmişlerdir. Aihua ve Buchmann, (2001) bu protozoonun yaşam siklusuyla su sıcaklığı arasında pozitif bir korelasyonun bulunduğunu vurgulamıştır. Yaptığımız çalışmada su parametrelerindeki değişimlerin, I. multifiliis pozitif ve negatif gruplardaki farklılıkları değerlendirildiğinde; su sıcaklığının ve çözünmüş oksijen miktarının istatistiki olarak önemli olduğu görülürken, pH'nın önemli olmadığı ortaya konmuştur. $\mathrm{Bu}$ protozoonun tespit edildiği su sıcaklığının daha yüksek olduğu görülmüştür. Enfeksiyonun genellikle su sıcaklığının çok daha yüksek olduğu dönemlerde tespit edilmesi, yine su sıcaklığıyla ters orantılı olan çözünmüş oksijen miktarının düşük olmasıyla da bağlantılı olabileceği düşünülmektedir. T. fultoni için bahsettiğimiz şekilde, su sıcaklığı ve çözünmüş oksijen miktarındaki yetiştiricilik aleyhine olan değişiklikler $I$. multifiliis enfeksiyonunun da oluş- 
masına zemin hazırlayabileceği net bir şekilde görülmüştür.

Çalışma boyunca incelenen balıklardan 4 tanesinde sadece Ocak ayında çoğu iki adet yumurta kesesine sahip metazoon parazit olan dişi Lernaea sp.'ler tespit edilmiştir. Enfestasyon oranı \%1.1 olarak hesaplanmış olup enfestasyon yoğunluğu ise önceki çalışmalarla benzer şekilde 8 olarak belirlenmiştir (Berry ve ark., 1991; Tokşen ve ark., 2014). Bu parazitin tespit edildiği havuzun boşaltılması sonucu yıl boyunca tekrar enfestasyona rastlanmamıştır. Parazitlerin tutundukları vücut yüzeylerinde daha önceki çalışmaların sonuçlarıyla uyumlu şekilde ödem ve yara izlerine rastlanmış olup, meydana gelen lezyonların çapının 5-9 mm arasında değiştiği görülmüştür (Berry ve ark., 1991, Bednarska ve ark., 2009). Çoğunlukla sazan türlerini enfeste eden Lernaea sp.,'nin bu çalışmada gökkuşağı alabalıklarında tespit edilmesi, bulunduğu işletmede sazan yetiştiriciliği yapılmasada aynı kaynak üzerinde yapılıyor olması ve aynı zamanda kullanılan su kaynağında doğal olarak bu balık türlerinin yaşıyor olmasına bağlanmıştır. Nitekim, Polonya'da toplu ölümlerin görüldüğü gökkuşağı alabalık işletmelerinde $L$. cyprinacea enfestasyonu saptanmış ve söz konusu balık türünün, sazan (Cyprinus carpio) ve benzeri balık türleriyle aynı ortamda yetiştirildiği vurgulanmıştır (Bednarska ve ark., 2009). Berry ve ark. (1991) dört yıl boyunca yürüttükleri çalışmada ilk $L$. cyprinacea enfestasyonunu her yıl yaz ortasında (Temmuz) tespit ettiklerini, parazitin en bol bulunduğu mevsimin ise sonbahar olduğunu belirtmişlerdir. Prevalansını ise Temmuz, Eylül ve Kasım aylarında $\% 100$ olarak hesaplamışlardır. Yine Bednarska ve ark., (2009)'nın belirttiğine göre normal koşullarda $L$. cyprinacea'nın optimum üreme sıcaklığı $23-30^{\circ} \mathrm{C}$ civarında olup, genellikle bu enfestasyona su sıcaklığının yüksek olduğu mevsimlerde rastlanmaktadır. Fakat su sıcaklığı $14^{\circ} \mathrm{C}$ 'nin altına düştüğü durumlarda ise parazitin yaşam siklusu durmakta ve çiftleşen dişi parazitler kışı ya da o dönemi herhangi bir konak üzerinde atlatabilmektedirler. Bu durum dikkate alındığında yaptığımız çalışmada parazitin tespit edildiği mevsim ve konak farklılığı net bir şekilde açıklanabilmektedir.

Bu çalışmanın bulgularından farklı olarak Türkiye'de gökkuşağı alabalıklarında Dactylogyrus sp., D. sphyrna, Gyrodactylus sp., Diplostomum spp., Clinostomum complanatum (metaserker), Pomphorhynchus laevis, Crepidostomum farionis, Hysterothylacium aduncum, $H$. gadi aduncum, Schulmanela petruschewskii rapor edilmiştir (Burgu ve ark., 1988; Öğüt ve Akyol, 2007; Pekmezci, 2010; Sağlam, 2013; Avsever ve ark., 2016; Çevrimel ve Soylu, 2017; Balta ve Balta, 2018b). Mevcut çalışmada Lernaea sp., dışında yukarıda bahsi geçen herhangi bir metazoon parazit tespit edilememiştir. Bu durumun ise yetiştiricilik yapılan ortamda söz konusu bazı parazitlerin ara konaklarının bulunup bulunma- ması veya balıkların beslenmesinde kullanılan yemlerin türü ve içeriğiyle ilgili olabileceği düşünülmektedir. Nitekim Pekmezci, (2010) yaptığı çalışmada $H$. gadi aduncum tespit ettiği gökkuşağı alabalıklarının birkaç ay öncesinde denizden avlanan hamsilerle beslendiğini, bu balıkların etkenin larva 3 formuyla enfekte olabileceğini ve dolayısıyla enfeksiyonun bundan kaynaklandığına vurgu yapmıştır. Skov ve ark. (2014) denizde yetiştirilen gökkuşağı alabalıklarında yaptıkları çalışmada $H$. aduncum tespit ettiklerini ve bu durumun ortamda artan ara/paratenik konaklarla (küçük balıklar, crustacealar vb.) ilişkili olduğunu belirtmişlerdir. Balıkların parazitler için bazen son bazen de arakonak olabildikleri dikkate alındığında, çiftliklerde yem olarak deniz balıklarının kullanılması, bazı metazoonların bulaşmalarında ve yayılmalarında risk teşkil ettiğini açıkça göstermektedir.

Sonuç olarak çalışma boyunca bulunan protozoonlar fırsatçı parazitler olup, konak üzerinde sayıları az olduğu dönemlerde ciddi bir enfeksiyon oluşturmazken, balıkların immun sistemini etkileyecek ve strese sokabilecek herhangi bir durumda önemli mortalitelere sebep olabilmektedirler. Yeterince stres faktörünün bulunduğu yetiştiricilik koşullarında bu gibi enfeksiyonların ortaya çıkması kaçınılmaz olmaktadır. Nitekim çalışmamız sonucunda bazı parametrelerin enfeksiyon varlığı üzerine olan etkisi ortaya konulmuş olup, kış mevsiminde enfeksiyon görülme oranının yaza göre 0.41 kat daha az olduğu belirlenmiştir. Özellikle su sıcaklığı, çözünmüş oksijen miktarı, balık boy ve ağırlıklarının enfeksiyon oluşumunda oldukça önemli olduğu görülmüştür. Çoğunlukla sazan türlerini enfeste eden $L$. cyprinacea, çalışma sırasında gökkuşağı alabalıklarında tespit edilmiştir. Aynı su kaynağı üzerinde sazan yetiştiriciliği yapılıyor olması ya da yetiştiricilikte kullanılan suda doğal olarak söz konusu balık türünün bulunması, bu gibi durumların oluşabileceğine işaret etmektedir. Tüm bu durumlar göz önünde bulundurulduğunda, olumsuz şartların bir arada olduğu yetiştiricilik koşullarında su kalitesinin mümkün olduğunca iyi olmasına, stok yoğunluğunun fazla olmamasına, suların yem artıkları ve ölü balıklarla kirletilmemesine dikkat edilmelidir. Aynı zamanda kültür ortamındaki balıklarla etkileşim içinde olan doğal ortamdaki balıkların, hem protozoon hem de metazoon faunasınının mevsimlere göre dağılımlarını belirlemeye yönelik çalışmaların yapılması ve yetiştiricilik açısından oluşturdukları risk faktörlerinin belirlenmesi gerekmektedir.

\section{Kaynaklar}

Aihua L, Buchmann K. Temperature- and salinitydependent development of a Nordic strain of Ichthyophthirius multifiliis from rainbow trout. J Appl Ichthyol 2001; 17: 273-6.

Altunay S, Yavuzcan Yıldız H. Kesikköprü Baraj Gölü'nde bir kafes işletmesinde yetiştirilen gökkuşağı 
alabalıklarının (Oncorhynchus mykiss Walbaum, 1792) ektoparazitolojik olarak incelenmesi. Ankara Üniv Tarım Bilim Derg 2008; 14(2): 154-62.

Atkinson SD, Bartholomew JL. Disparate infection patterns of Ceratomyxa shasta (Myxozoa) in rainbow trout (Oncorhynchus mykiss) and Chinook salmon (Oncorhynchus tshawytscha) correlate with internal transcribed spacer-1 sequence variation in the parasite. Int J Parasitol 2010; 4: 599-604.

Avsever ML, Selver MM, Yazıcıoğlu Ö, Tokşen E, Tay S, Erdal G, Günen MZ. The first report of diplostomiasis from cultured rainbow trout (Oncorhynchus mykiss) in Turkey. Ankara Üniv Vet Fak Derg, 2016; 63: 377-81.

Balta F, Balta ZD. Gökkuşağı alabalığı (Oncorhynchus mykiss) yavrularında görülen Hexamitozis'in tanı ve tedavisi. Anadolu Çev ve Hay Dergisi 2018a; 1: 4-8.

Balta F, Balta ZD. Kültürü yapılan gökkuşağı alabalıklar (Oncorhynchus mykiss)'Inda Gyrodactylus spp. enfeksiyonu. Anadolu Çev ve Hay Dergisi 2018b; 3: 141-4.

Balta F, Balta ZD. Kültürü yapılan karadeniz alabalığı (Salmo coruhensis syn. Salmo labrax)'nda görülen bazı dış siliat protozoon parazit enfestasyonları ve tedavileri. Anadolu Çev ve Hay Dergisi 2017; 2: 2933.

Balta F, Kayış S, Altınok I. External protozoan parasites in three trout species in the Eastern Black Sea region of the Turkey: intensity, seasonality, and their treatments. B Eur Assoc Fish Pat 2008; 28(4): 157.

Bednarska M, Bednarski M, Soltysiak Z, Polechonski $\mathrm{R}$. Invasion of Lernaea cyprinacea in rainbow trout (Oncorhynchus mykiss). Acta Sci Pol Med Vet 2009; 8(4): 27-32.

Berra TM, Au RJ. Incidence of black spot disease in fishes in Cedar Fork Creek, Ohio. Ohio J Sci 1978; 78(6): 318-22.

Berry CR, Babey GJ, Shrader T. Effect of Lernaea cyprinacea (Crustacea: Copepoda) on stocked rainbow trout (Oncorhynchus mykiss). J Wildlife Dis 1991; 27(2): 206-13.

Buchmann K, Bresciani J. Monogenea (Phylium Platyhelminthes). Woo PTK eds In: Fish Diseases and Disorders. $2^{\text {nd }}$ Volume 1: Protozoan and Metazoan Infections. UK: CAB İnternational, Wallingford, 2006; pp. 297-344.

Buchmann K, Bresciani J. Parasitic infections in pond -reared rainbow trout Oncorhynchus mykiss in Denmark. Dis Aquat Organ 1997; 28(2): 125-38.
Buchmann K. An Introduction to Fish Parasitological Methods-Classical and Molecular Techniques. Copenhagen: Biofolia Press, 2007.

Burgu A, Oğuz T, Körting W, Güralp N. İç Anadolu'nun bazı yörelerinde tatlısu balıklarının parazitleri. Etlik Vet Mikrobiyol Derg 1988; 3(6): 143-65.

Bush AO, Lafferty KD, Lotz JM, Shostak AW. Parasitology meets ecology on its own terms: Margolis et al. revised. J Parasitol 1997; 83: 575-83.

Çevrimel DS, Soylu E. The occurrence of Pomphorhynchus laevis (Acanthocephala) in cagereared rainbow trout (Oncorhynchus mykiss) from Işıklı Spring, Çivril, Turkey. Ege J Fish Aqua Sci 2017; 34 (3): 255-60.

Dick TAC, Chambers C, Isinguzo I. Cestoidea (Phylium Platyhelminthes). Woo PTK eds In: Fish Diseases and Disorders. Second Volume 1: Protozoan and Metazoan Infections. UK: CAB International, Wallingford, 2006; pp. 391-416.

Dickerson HW. Ichthyophthirius multifilis and Cryptocaryon Irritans (Phylum Ciliophora). Woo PTK. Ed. In: Fish Diseases and Disorders. Volume 1: Protozoan and Metazoan Infections. Second Press. UK: CAB International, Wallingford; 2006; pp. 116-53.

Diler Ö, Görmez Ö, Terzioğlu S, Bayrak H. Gökkuşağı alabalığı (Oncorhynchus mykiss) yetiştiriciliğinde görülen Spironucleosis enfeksiyonlarının tedavisinde Artemisia campestris (L)'in kullanımı. Act Aqua $\operatorname{Tr} 2018 ;$ 14(4): 312-23.

Durborow RM. Protozoon Parasites. Southern Regional Aquculture Center, 2003: 4701.

Emre Y. Alabalık yetiştiriciliği. TC Başbakanlık Güneydoğu Anadolu Projesi Bölge Kalkınma İdaresi Başkanlığı Yayını, 2004.

Erer H. Balık Hastalıkları. Konya: Selçuk Üniversitesi Basımevi, 2002; s. 4-5.

Jørgensen T.R, Larsen TB, Buchmann K. Parasite infections in recirculated rainbow trout (Oncorhynchus mykiss) farms. Aquaculture 2009; 289: 91-4.

Karasev AB, Mitenev VK, Kalinina NR. Parasite fauna of cage-reared rainbow trout Oncorhynchus mykiss (Walbaum 1792) research in freshwater farms (Kola Peninsula, Russia). B Eur Assoc Fish Pat 1997; 17(5): 177-9.

Karvonen A, Rintamäki $P$, Jokela J, Valtonen ET. Increasing water temperature and disease risk in aquatic systems: Climate change increases the risk of some, but not all, diseases. Int J Parasitol 2010; 40(3): 1483-8. 
Lom J, Dyková I. Protozoan Parasites of Fish. Volume 26: Developments in Aquaculture and Fisheries Science. Amsterdam: Elsevier Science Publishers, 1992; p. 315-6.

Lom J, Hoffman GL. Geographic distribution of some species of Trichodinids (Ciliata: Peritricha) parasitic on fishes. J Parasitol 1964; 50(1): 30-5.

Maceda Veiga A, Monroy M, Salvado H, Cable J, De Sostoa A. Ectoparasites of native cyprinid Barbus haasi: First record of Trichodina acuta and Trichodina fultoni in Iberian catchments. B Eur Assoc Fish Pat 2013; 33(6): 187.

Moravec F. Metazoan Parasites of Salmonid Fishes of Europe. Praha-Czech Republic: Academia Publishers, 2004.

Öğüt $H$, Akyol A, Alkan MZ. Seasonality of lchthyophthirius multifiliis in the Trout (Oncorhynchus mykiss) Farms of the Eastern Black Sea Region of Turkey. Turk J Fish Aquat Sci 2005; 5(1): 23-7.

Ögüt $H$, Akyol A. Prevalence and intensity of ectoparasites in rainbow trout (Oncorhynchus mykiss) from larvae stage to market size in Turkey. Isr J Aquac 2007; 59(1): 23-31.

Öge $\mathrm{H}$. Balık tüketiminde ekonomik ve sağlık yönünden önemli parazitler. Türkiye Parazitol Derg 1999; 23(4): 440-5.

Özer S, Koyuncu E, Dönmez E, Bulduklu PS, Erdoğan S. Mersin'de yetiştiriciliği yapılan gökkuşağı alabalıklarındaki (Oncorhynchus mykiss, walbaum, 1792) saptanan ektoparazit protozoonlar. Pendik Vet Mikrobiyol Derg 2010; 37(1): 43-52.

Paperna I, Dzikowski R. Digenea (Phylium Platyhelminthes). Woo PTK eds In: Fish Diseases and Disorders. Second Volume 1: Protozoan and Metazoan Infections. UK: CAB International, Wallingford, 2006; pp. 345-90.

Pekmezci Z. Samsun yöresinde yetiştirilen gökkuşağı alabalıklarında (Oncorhynchus mykiss) metazoon parazit faunası. Doktora tezi, Ondokuz Mayıs Üniv Sağ Bil Ens, Samsun, 2010.

Pillay TVR. Aquaculture and Environment. Blackwell Scientific Publication, 1992; p. 189.

Poulin S, Sara MM, Javad S. A survey on ectoparasite fauna of cold water fish farms in Mazandaran province, Iran. Glob Vet 2012; 8 (1): 1014.

Rintamiiki-Kinnunen P, Valtonen ET. Epizootiology of protozoans in farmed salmonids at northern latitudes. Int J Parasitol 1997; 27(1): 89-99.
Rubio-Godoy M, Paladini G, Freeman MA, GarcíaVásquez A, Shinn AP. Morphological and molecular characterisation of Gyrodactylus salmonis (Platyhelminthes, Monogenea) isolates collected in Mexico from rainbow trout (Oncorhynchus mykiss Walbaum). Vet Parasitol 2012; 186(3-4): 289-300.

Saghari Fard MR, Jørgensen A, Sterud E, Bleiss W, Poynton SL. Ultrastructure and molecular diagnosis of Spironucleus salmonis (Diplomonadida) from rainbow trout Onchorhyncus mykiss in Germany. Dis Aquat Organ 2007; 75(1): 37-50.

Sağlam N. Infection of Hysterothylacium aduncum (Namatoda: Anisakidae) in farmed rainbow trout (Oncorhynchus mykiss Walbaum, 1792). Afr J Agric Res 2013; 8(47): 5953-7.

Saygı G. Genel Parazitoloji. Türkiye: Esnaf Ofset Matbaacılık, 1999.

Schisler GJ, Walker PG, Chittum LA, Bergersen EP. Gill ectoparasites of juvenile rainbow trout and brown trout in the upper Colorado River $\mathrm{J}$ Aquat Anim Health 1999; 11(2): 170-4.

Scholz T. Parasites in cultured and feral fish. Vet Parasitol 1999; 84(3-4): 317-35.

Skovgaard A, Buchmann K. Tetracapsuloides bryosalmonae and PKD in juvenile wild salmonids in Denmark. Dis Aquat Organ 2012; 101(1): 33-42.

Skov J, Mehrdana F, Marana MH, Bahlool QZM, Jaafar RM, Sindberg D, Jensen HM, Kania P, Buchmann K. Parasite infections of rainbow trout (Oncorhynchus mykiss) from Danish mariculture. Aquaculture 2014; 434: 486-92.

Tokşen E, Arif Zoral M, Şirin C. Occurence of Lernaea spp. infection in rainbow trout (Oncorhynchus mykiss) farmed in Turkey. B Eur Assoc Fish Pat 2014; 35(1): 8-13.

Tonguthai K. Control of freshwater fish parasites: A Southeast Asian perspective. Int J Parasitol 1997; 21(10): 1185-91. 